\title{
Agents and Actors at Aanischaaukamikw Cree Cultural Institute
}

Agents et acteurs de l'Institut culturel cri Aanischaaukamikw

\section{Minnie Coonishish}

\section{(2) OpenEdition \\ 1 Journals}

Electronic version

URL: https://journals.openedition.org/iss/3129

DOI: $10.4000 /$ iss. 3129

ISSN: 2306-4161

Publisher

ICOM - International Council of Museums

\section{Printed version}

Date of publication: 18 December 2021

Number of pages: $67-76$

ISBN: 978-92-9012-446-7

ISSN: 2309-1290

\section{Electronic reference}

Minnie Coonishish, "Agents and Actors at Aanischaaukamikw Cree Cultural Institute", ICOFOM Study Series [Online], 49-1 | 2021, Online since 18 December 2021, connection on 08 January 2022. URL: http://journals.openedition.org/iss/3129 ; DOI: https://doi.org/10.4000/iss.3129 


\title{
Agents and Actors at Aanischaaukamikw Cree Cultural Institute
}

\section{Minnie Coonishish}

\author{
Aanischaaukamikw Cree Cultural Institute - \\ Ouje-Bougoumou, Canada
}

ABStRACT

Aanischaaukamikw Cree Cultural Institute (ACCI) opened in 2011, but the idea had been around for many decades. Since 2011, we have been working to bring Eeyou world views and values to life within this cultural space, adapting aspects of the European tradition of museology to meet the needs of our communities. This paper presents an overview of our decolonising practice as we move into our second decade of existence as the cultural heart of Eeyou Istchee.

Key words: Eeyou Istchee, Indigenous self representation, Indigenous sovereignty, belongings

$$
\text { RÉSUMÉ }
$$

\section{Agents et acteurs de l'Institut culturel cri Aanischaaukamikw}

L'Institut culturel cri Aanischaaukamikw (ACCI) a ouvert ses portes en 2011, mais on en rêvait depuis plusieurs dizaines d'années. Depuis 2011, nous travaillons à faire vivre la vision du monde et les valeurs Eeyou 
au sein de cet espace culturel, adaptant divers aspects de la tradition européenne de la muséologie pour répondre aux besoins de nos communautés. Le présent document offre un survol de nos pratiques de décolonisation au moment où nous entrons dans notre deuxième décennie d'existence en tant que cœur culturel d'Eeyou Istchee.

Mots clés : Eeyou Istchee, autoreprésentation autochtone, souveraineté autochtone, possessions.

\section{*}

\section{Introduction}

Located in Ouje-Bougoumou, ACCI is the regional cultural institute for Eeyou Istchee, a self-governing region in what is now known as Quebec, that has 10 Eeyou communities: Whapmagoostui (Great Whale); Chisasibi (forcibly relocated from Fort George Island); Eastmain; Wemindji (Paint Hills); Waskaganish (Rupert's House); Nemaska; Waswanipi; Ouje-Bougoumou; Mistissini (Mistassini Post) and Washaw Sibi. Activities related to the Institute include educational programming related to Eeyou culture, management of a cultural archive, library, museum collection, and a permanent exhibition. Anishinaabe architect Douglas Cardinal designed the original layout of Ouje-Bougoumou on the edge of Lake Opemiska and also designed our facility, which sits on the inner 'medicine wheel' layout of the centre of Ouje-Bougoumou along with the band office, a church, and corporate offices, including a post office. These buildings surround a shabtuan ${ }^{1}$ style open building that is used in winter as an outdoor hockey rink and in summer for outdoor gatherings.

Our mandate explains our mission, which is imbued with Eeyou values:

...Aanischaaukamikw flows from the knowledge that Cree culture must be captured, maintained, shared, celebrated, and practiced... it is a living, breathing symbol of our determination to preserve and share the stories and legends, the music, the pictures, and the physical objects that show our unique interaction with the land, expressed through hunting, fishing, trapping, and underscored with a reverence for the land we have walked since time immemorial.

(Aanischaaukamikw, 2011b)

\footnotetext{
I. We are not italicising this word, it is in our language, liyiyiumuwin, because there is no equivalent translation in English and, therefore, this word (and others) should be used in English and not be considered 'foreign.'
} 
Aanischaaukamikw Cree Cultural Institute opened in 2011 (Pashagumskum et al., 2016), after decades of planning by Eeyou Elders and community members. ACCI is based in a self-governing region in what is now known as the Eastern James Bay region of Quebec, Canada, ${ }^{2}$ and as such, many of the original policies and ways of working followed the existing practices of Eeyou Cree communities and the Cree Nation of Eeyou Istchee. For example, our staff leave allowances include paid time off for traditional activities, which are usually used in the autumn and spring seasons for the moose and goose hunts.

However, many of the founding policies, procedures and practices put in place in our library, archives and museum collections were based on Euro/Western museological standards. For the past few years, we have been responding to the needs of Eeyou community members and revising our ways of working within our collection areas to centre on Eeyou values. This paper presents an overview of the ways we are decolonising our practices within our cultural institution (Lonetree, 2012).

\section{Our Belongings: Treasures that Keep us Alive}

The importance of our belongings ${ }^{3}$ and how they have kept us alive for countless generations can be illustrated by this personal anecdote, which can be directly applied to how we are preserving our culture for our future generations. Thus, I'd like to share a personal story about survival from my childhood:

When I was 7 years old, my jimshoom ${ }^{4}$ and my gookum were traveling by sled with our dog pulling the sled. As we were traveling beside a river, all of sudden the ice beneath us cracked open.

I froze as I watched my jimshoom holding the dog and the sleigh, the sleigh was right over the crack and he started pulling it towards the shore, to the safe area. My gookum jumped over to the other side.

I was alone on the other side, standing still, not knowing what to do. As I watched all this, time seemed to slow down. Then I heard my gookum yelling "Minnie, jump!" (in Cree).

I looked down at the dark water flowing as the crack grew wider. I looked up at my gookum's face, I saw despair and knowing she couldn't swim, I gathered all my strength into that jump and leaped

2. Please note that we are purposely choosing not to be defined by the colonial borders imposed on this land and consider the 'border' a theoretical colonial construct, after Simpson (20I4).

3. We chose to refer to our object collections as belongings after Wilson (20I6). See also Collections Stewardship (20I8).

4. Jimshoom is our word for grandpa / grandfather. Gookum is our word for grandma / grandmother. 
across the large crack on the ice. I felt my gookum's grasp on my coat, then I knew I was safe!

Today, thinking back to what we had on that sleigh, I understand why my jimshoom fought hard to pull the sleigh. All our needs were there. Our tools, our food, etc...

That year they took me on the land, I remember my gookum taking care of each item, whether it was clothes, tools, my snowshoes, etc. Each time I used my snowshoes, I had to hang them outside on a tree. I had to hang up my moccasins to dry at the end of each day. I had to take care of my axe and not lose it.

With a little glimpse of our history, I am honored and grateful for our Elders' and founding members' vision of Aanischaaukamikw. Today, Aanischauukamikw continues to implement the mission and vision of our ancestors.

\section{Role of Aanischaaukamikw}

Our research philosophy is 'Nothing about us, without us' (Aanischaaukamikw, 2019b), meaning that we are the authorities and experts on all aspects of our own culture, as guaranteed by the United Nations Declaration on the Rights of Indigenous Peoples (United Nations, 2007). Any cultural research projects that are done by outsiders in our region should consult with us and follow our Research Policy and Procedures. This is mandatory for any research that is undertaken on the collections at Aanischaaukamikw. Our Research Policy centres on the OCAP principles - Ownership, Control, Accession, Possession - that were developed by the First Nations Institute of Canada (First Nations Governance Centre, n.d.). Our Guiding Principles for research prioritise the needs of our communities: for example, all research must be useful for our communities; research must be done with, or by, Eeyou community members; and any publications must have Eeyou community members as co-authors (Aanischaaukamikw, 2019a).

Within Eeyou Istchee, our role is to encourage good communication and interaction with the cultural coordinators in each community. We provide assistance and support for preventative measures, including advising on proper care and protection for collections (objects, archives, libraries, digital and analogue media). We partner with many organisations, including museums and heritage organisations outside of our region, for hosting internships and work placement programs. We ensure that all of our cultural programming and teachings involve Elders and other knowledge keepers from our region. 


\section{Programming at Aanischaaukamikw}

The Programs Department is the largest department at Aanischaaukamikw and includes Collections (library, museum, archives), Archaeology, Educational Programming, Gatherings and Special Events. The Educational Programming section organises school visits for groups from inside and outside of the region. We have a partnership with a school in Chibougamau, a town in Quebec that is approximately $60 \mathrm{kms}$ away from Ouje-Bougoumou, to deliver a Cree-focused history course for their secondary school students. We have worked with school groups to organise visits from as far away as Maine and Georgia. We provide outreach to schools through the creation of educational programming by creating teaching kits and lesson plans for the Cree School Board.

We host workshops and training sessions. We have hosted artist-in-residencies for Cree artists, and creative workshops linked to wider Indigenous events such as during Rock Your Mocs week, when we had Elders come in to teach younger audiences how to make moccasins. Special events are an exciting part of our programming. We produced and toured a theatrical production entitled Mind's Eye, which was based on traditional Eeyou knowledge shared through storytelling (Marshall \& Masty, 2015). In 2018, we hosted the Montreal Symphony Orchestra for a performance of Chaakapesh, an opera based on our traditional stories and legends.

\section{Exhibitions at Aanischaaukamikw}

Our inaugural exhibit, Aa Chiiwaaschaaniwich: Reclaiming the Ways of Our Ancestors (Aanischaaukamikw, 2011a), features contemporary themes that bring past and present together in our exhibition space: tools, childcare, crafts, transportation, sacred and ceremonial belongings, the history of our region (from ancient to modern times), clothing (mittens, moccasins, headgear, and coats), camp life, bags and accessories. Our displays are put into our cultural context using quotes from Elders and knowledge keepers, as well as by including historic and modern photographs to show how objects were used in the past and the continuation of this use, and how we have adapted our technologies for our contemporary needs. The exhibit has around 150 belongings on display, including items from our permanent collection, as well as loans from museums from outside our region, Cree community members, and Cree organisations.

Prior to becoming Executive Director in 2020, I lent Aanischaaukamikw some very special belongings: three handstitched women's fabric blouses made many years ago by my grandmother Nanny Wapachee Jolly of Mistissini, from fabric purchased at the Hudson Bay Trading Post; a fabric cap made by Nanny for my son when he was young; a niimaapaan (dragline for pulling freshly killed small animals, like beavers, back to camp) made from jute with embroidery thread tassels as well as old and new decorations, that dates to the 1980s; a handsewn fabric bag made by Nanny, used for carrying tea and sugar while we travel in the bush; a sewing kit; a fish hook made by my grandfather Billy 
Jolly; a metal needle for lacing snowshoes made by Billy for his wife Nanny; a pair of small round snowshoes (usually for wearing around camps) made by Billy that I found in a shed at his camp; larger pointy snowshoes (usually used for travelling) belonging to Isaac Coonishish that were made in Mistissini at a snowshoe factory; and the most special thing is a maatahiikan (also known as ulu, but that is the Inuit term), a scraper for beaver skin that was made by William Iserhoff, in the late 1800s or early 1900s, out of bear bone and metal. This was made for his daughter Maggie before she got married. Before her passing, Maggie gave it to my grandmother Nanny before she got married, and Nanny then gave it to me.

With these sentimental gifts passed down to me from my gookum, it was an honour, but I felt I couldn't use them because they are my treasures. I had heard about the loan program by word of mouth, so I communicated with the museum. Today, I am at peace knowing they are kept at Aanischaaukamikw.

In 2015, we received a grant from Canadian Heritage's Museums Assistance Program to develop a travelling exhibit so that we could take our Eeyou culture on the road to new audiences outside of our region. This project had an all-Cree content development team that was led by two Cree curators who are also artists and crafts people. All of the texts and labels were written by one of the Cree curators, which were presented in our Cree syllabics, English and French languages. All of the designs were approved by the Cree content development team. The physical layout of the exhibit followed our Eeyou world view for clockwise wayfinding based on the movement of the sun over our Earth, with the belongings displayed in ways that maintain their ongoing connection to our community members, their makers, and their makers' ancestors both past, present, and future (Morin, 2014; Wilson, 2016).

The resulting travelling exhibit, Footprints: A Walk Through Generations (Aanischaaukamikw, 2017), included over 150 belongings, many of which were lent by community members and Cree entities. The exhibit took two years to develop and assemble. It opened in 2017 at Aanischaaukamikw in a multi-use performance and display space, the Billy Diamond Hall, named after an extremely influential and important Chief. The exhibit travelled to all of our 10 Cree communities (including Whapmagoostui, the fly in community), accompanied by three young people from Cree communities who set it up and acted as guides. Footprints travelled to a few host venues in Quebec including a mining site. It was on display at the Canadian Museum of History in 2019, where it was exhibited for six months. As of 2020, it is in storage so we can refurbish it for further travels. The organic nature of most of the belongings in this exhibit meant that they needed to be rotated to prevent damage from light exposure. We intend to continue to tour the exhibit from 2022 to 2025. The exhibit won some national awards, including the 2018 Governor General's History Award for Excellence in Museums: History Alive! and the 2018 Canadian Museum Association's Award of Outstanding Achievement in Exhibitions - Cultural Heritage. 
Another recent exhibition project was a collaboration with Dr. Frances Wilkins, an ethnomusicologist and lecturer at the University of Aberdeen in Scotland. Scots and Eeyou Istchee have been connected for many centuries because of the fur trade. This exhibit was looking at the transfer of music between these regions, particularly fiddle music, which is still popular in Eeyou Istchee today. We worked together on the text panels to ensure they were written from a decolonial perspective that placed our world view and historical memories on a par with those of the Scots. This exhibit opened in Aberdeen in 2018. We are planning to tour the graphic panels around Eeyou Istchee in 2021.

\section{Centring the Needs of the Community in Exhibitions}

In addition to the many ways that we centre the needs of our communities that have already been mentioned, we have some specific examples of how we apply these principles in our collections work. For example, we have a successful community loans program in which our community members can lend us ceremonial belongings for safekeeping in our secure, climate-controlled storage facility (Aanischaaukamikw, 2019c). We work beyond typical Eurocentric museum loan standards to provide return access to these belongings at short notice, if they are required for a ceremony. This includes removing belongings from display, which was done recently when a lender wanted to use accessories she had lent us for our 'baby care' display in her second child's walking out ceremony. This is the ceremony in which a child is introduced to the land and animals and walks on the Earth for the first time. Other ceremonial belongings may be lent to us with instructions that only a family member of the lender can handle the belonging directly, because the belonging is imbued with a special protective relationship built between the owner and the belonging. This was the case with a makaahiikan lent as part of a child's first snowshoe walk ceremonial outfit. A makaahiikan is carved from wood and acts as a scoop for snow and ice as well as a walking stick that guides the owner safely over dangerous terrain. We provide secure, climate-controlled storage for community loans with no obligation for their display, and when we return community loans, we made custom boxes so they can be stored safely.

\section{Centring our World View in our Library}

Our documentation centre includes a research library and archival collections. Our library includes material relevant to our region - mostly works of nonfiction. We have an estimated 5000 items in our library at present, and the collection continues to grow with generous donations. We have some rare books, periodicals and reference materials. The bulk of our collection was formed from personal libraries donated by retired anthropologists who worked in the region in the late $20^{\text {th }}$ century: Richard Preston, Harvey Feit, Cath Oberholtzer and Pierrette Desy. Our librarian, Annie Bosum, has been part of Aanischaaukamikw since the earliest days of planning the facility; and 
as a member of Ouje-Bougoumou Cree Nation, she has been instrumental in shaping the library to represent Cree world views.

For example, when faced with choosing which library classification system we should use at Aanischaaukamikw, we realised that the systems used in most non-Indigenous libraries (Dewey, Library of Congress) did not adequately reflect the complexity of Indigenous resources. With her specialist knowledge of the Eeyou Istchee region, Annie was able to adapt the Brian Deer Classification (BDC) system for use at Aanischaaukamikw (Bosum \& Dunne, 2017). BDC was originally developed by Brian Deer, a Mohawk man from Kahnawake, specifically for use in Indigenous libraries. BDC has a flexible structure that can be customised for each region that chooses to implement it.

\section{Sharing our Work: Inside and Outside of Eeyou Istchee}

We disseminate our work in a variety of ways with the goal of reaching as many Eeyou community members as possible, including those who choose to live in urban centres outside of our region. Some of the ways we share our collections include our online collections page, where users can search our library, museum and non-restricted archival collections; a blog platform (http://aanischaaukamikw.blogspot.com/) where we share stories about events and details about our work; we have a Facebook page; we create project-specific Facebook pages for gathering community knowledge when appropriate; we contribute seasonally themed articles to the Air Creebec (our regional airline) inflight magazine; we present at conferences; and we contribute to publications.

A post on our blog page shares details of how to make paint and pigments from materials foraged from the land around Ouje-Bougoumou, by Eeyou artist Margaret Orr (2020). From 2019 to 2020, Margaret worked as a specialist researcher on a project funded by the Arts Council of Canada's 'Creating, Knowing, and Sharing' funding stream. The project was to do community-based research with Elders and knowledge keepers to investigate the meaning of the historic painted caribou coats (often called 'Naskapi' coats) that are in many museum collections internationally (Orr et al., 2021). Our research has revealed that these coats have an important tradition in our region, which has sometimes been over-written as 'Naskapi' by outsiders, because of their confusion about the connections between Eeyou and Naskapi peoples (Bishop \& Brousseau, 2018; Mailhot, 1986). When Margaret had to shelter on site in Ouje-Bougoumou during the early days of the COVID-19 pandemic, she took advantage of the spring weather and gathered different materials to show how our ancestors used what was around them to make the paints and pigments that we see on these painted coats today.

\section{Conclusion}

From the initial concept of having our own cultural institute located within the village of Ouje-Bougoumou, we have centred the needs of the communities of 
Eeyou Istchee in achieving this reality. Today, almost 10 years after we opened the doors to Aanischaaukamikw in 2011, we continue to work to centre Eeyou world views and values in our day-to-day work as we transform concepts of museology to work for our communities. This article has given examples from policy, procedures and practice to demonstrate how we are both agents and actors in this museological process.

\section{References}

Aanischaaukamikw Cree Cultural Institute. (2011a). Aa Chiiwaaschaaniwich: Reclaiming the ways of our ancestors [Exhibition catalogue].

Aanischaaukamikw Cree Cultural Institute. (2011b). Mission and vision [Brochure].

Aanischaaukamikw Cree Cultural Institute. (2017). Footprints: A walk through generations [Exhibition catalogue].

Aanischaaukamikw Cree Cultural Institute. (2019a). Aanischaaukamikw Cree Cultural Institute - general statement of research principles. http://www.creeculturalinstitute.ca/wp-content/uploads/2019/01/research_principles.pdf

Aanischaaukamikw Cree Cultural Institute. (2019b). Beyond inclusion - decolonising through self-representation in Eeyou Istchee. Active History. http:// activehistory.ca/2019/03/beyond-inclusion-decolonising-through-self-representation-in-eeyou-istchee/

Aanischaaukamikw Cree Cultural Institute. (2019c). Beyond property and trade: Establishing a community loans program. Canadian Museums Association MUSE (Jan/Feb), 14-19.

Aanischaaukamikw Cree Cultural Institute, \& Wilkins, F. (2021). Words matter: Exhibition text collaboration process for Nimitaau: Let's dance [Manuscript submitted for publication].

Bishop, J., \& Brousseau, K. (2018). I speak Cree, not Innu: Ethnically united, ethnonymically divided? In S. Gervais, R. Iacovino, \& M. A. Poutanen (Eds.), Engaging with diversity: Multidisciplinary reflections on plurality from Quebec (Vol. 23), (pp. 159-183). Peter Lang.

Bosum, A., \& Dunne, A. (2017). Implementing the Brian Deer classification scheme for Aanischaaukamikw Cree Cultural Institute. Collection Management, 42(3-4), 280-293. https://dx.doi.org/10.1080/01462679.2017.13 40858

Collections Stewardship. (2018). Lexicon Task Force report 2018, words matter: Lexicon usage and Indigenous cultural belongings. https://staticl.squarespace.com/static/58a5dc6cb3db2b9edd19c676/t/5bf38530758d4 
63e99935720/1542686004821/CSAAM+Lexicon+Task+Force_+Final+Report.pdf

First Nations Information Governance Centre. (n.d.) Understanding the First Nations principles of OCAP. https://fnigc.ca/wp-content/ uploads/2020/09/2be8f15f2eff14b1f122b6a26023836a_fnigc_ocap_brochure_en_final_0.pdf

Lonetree, A. (2012). Decolonizing museums: Representing Native America in national and tribal museums. University of North Carolina Press.

Mailhot, J. (1986). Beyond everyone's horizon stand the Naskapi. Ethnohistory, 33(4), 384-418. https://dx.doi.org/10.2307/482040

Marshall, S., \& Masty, E. (2015). Mind's eye: Stories from Whapmagoostui. Aanischaaukamikw Cree Cultural Institute.

Morin, P. (2014). My life as a museum, or, performing Indigenous epistemologies. In S. Brophy \& J. Hladki (Eds.), Embodied politics in visual autobiography (pp.137-152). University of Toronto Press.

Orr, M. (2020, June 19). Making paint pigments. ACCI News. http://aanischaaukamikw.blogspot.com/2020/06/making-paint-pigments.html

Orr, M., Mukash, N., \& Menarick, P. (2021). Rediscovering the tradition of painted caribou belongings in Eeyou Istchee - a community based and community led research project. KULA: Knowledge Creation, Dissemination, and Preservation Studies Special Issue: Indigenous Knowledges, 5(1), 1-10.

Pashagumskum, S., Menarick, P., Phillips, L., Laurendeau, G., \& Scott, K. (2016). Seeing ourselves: The path to self-curation, cultural sovereignty and self-representation in Eeyou Istchee. In K. Hele (Ed.), Survivance and reconciliation: 7 forward / 7 back: 2015 Canadian Indigenous Native Studies Association conference proceedings (pp. 60-87). Aboriginal Issues Press.

Simpson, A. (2014). Mohawk interruptus: Political life across the borders of settler states. Durham, NC: Duke University Press.

United Nations Human Rights Office of the High Commissioner. (2007). Declaration on the Rights of Indigenous People. http://www.ohchr.org/EN/ Issues/IPeoples/Pages/Declaration.aspx

Wilson, J. (2016). Gathered together: Listening to Musqueam lived experiences. Biography, 39(3), 469-494. 